\title{
Regulation of Erythropoiesis in Suckling Rabbits with and without Postnatal Anemia: Partial Suppression of Production/Release of Erythropoiesis Stimulating Factor(s) by Iron Supplements
}

\author{
PER H. HOLTER, TRULS SANENGEN, SVERRE HALVORSEN, AND HARALD E. REFSUM \\ Laboratory for Clinical Physiology and Departments of Pediatrics and Pathology, \\ Ullevaal Hospital, Oslo, Norway
}

\begin{abstract}
The postnatal anemia in rabbits is accompanied by a marked rise in the plasma erythropoiesis stimulating factor(s) (ESF). The purpose of this study was to establish whether the increase in plasma ESF is only related to the anemia, or whether other mechanisms also are involved. Two matched groups of rabbits were studied from the 15 th to the 36 th day after birth. One group received iron parenterally and had no postnatal fall in hemoglobin concentration $(\mathrm{Hb})$, the other developed the usual anemia. In both groups plasma ESF was undetectable on the 15th day, and also on the 22nd day, despite a marked fall in $\mathrm{Hb}$ in the untreated group and rise in the iron-treated group. Thereafter plasma ESF showed a slight, continuous rise in the nonanemic rabbits, in contrast to a marked, transient rise with maximum on the 29th day in the untreated group. On the 36th day there was no difference between the groups. In the iron-treated group the reticulocyte production rate remained unchanged, while the $\mathrm{Hb}$ mass rose continuously. In the untreated animals there was an initial decline in reticulocyte production rate, while Hb mass showed a slight increase. From the 29th day, however, reticulocyte production rate rose to the same level as in the iron-treated group and $\mathrm{Hb}$ mass rose markedly. In conclusion, the rise in plasma ESF during the postnatal anemia in rabbits is only in part related to the low Hb. Hypoxia-independent mechanisms, probably related to the growth and maturation per se also are involved. The lack of erythropoietic response to the rise in plasma ESF is due to lack of available iron. (Pediatr Res 21: 1-4, 1987)
\end{abstract}

\section{Abbreviations}

ESF, activity of erythropoiesis stimulating factor(s)

$\mathrm{Hb}$, whole blood hemoglobin concentration

Hct, hematocrit

MCHC, mean corpuscular hemoglobin concentration

Rt, reticulocyte count

Rt prod, reticulocyte mass production rate

Hb mass, total hemoglobin mass

Received February 24, 1986: accepted August 6, 1986

Per H. Holter, Laboratory for Clinical Physiology, Ullevaal Hospital, 0407 Oslo 4. Norway.

Supported by the Norwegian Research Council for Science and the Humanities. V. Fürst Research Foundation for Clinical Chemistry and Clinical Physiology, and the Norwegian Society for Fighting Cancer.
A postnatal fall in $\mathrm{Hb}$ is common to most mammals and is termed the early anemia. In humans, the anemia is most severe in the premature infant. The mechanisms of this drop in $\mathrm{Hb}$ are poorly understood. Comparative studies may give information which can give rise to new hypothesis in the human. The erythropoiesis in adult mammals is regulated mainly through erythropoietin in response to variations in renal tissue $\mathrm{O}_{2}$ tension (1), but other factors may also be involved (2). The tissue $\mathrm{O}_{2-}$ dependent mechanism seems to be established already during fetal life (3-6), but several studies indicate that the regulation of erythropoiesis in newborn animals differs from that which is observed in the adult $(4,7-13)$.

Previous studies have shown that plasma ESF in young rabbits is very low during the early phase of the postnatal fall in $\mathrm{Hb}$, but increases markedly during the 3rd and 4th wk after birth (10). This may suggest that the regions governing the erythropoietin production/release become increasingly sensitive to low $\mathrm{Hb}$ and tissue $\mathrm{O}_{2}$ tension during this period (10). The possibility also exists that the increase in plasma ESF only in part is due to hypoxic stimulation, and that other, hypoxia-independent mechanisms play a role for the regulation of erythropoiesis at this age. The fact that the postnatal fall in $\mathrm{Hb}$ in rabbits can be avoided by parenteral iron supplements $[14,15)$ makes it possible to distinguish between anemic-hypoxia dependent and independent regulating mechanisms.

The purpose of this study was thus to establish whether the rise in plasma ESF during the postnatal anemia in rabbits is due to the low $\mathrm{Hb}$ and the possible tendency to fall in tissue $\mathrm{O}_{2}$ tension only, or if hypoxia-independent mechanisms also are involved. To accomplish this, plasma ESF, $\mathrm{Rt}, \mathrm{Hb}$, and Hct were determined from the 15 th to the 36th day after birth in two matched groups of rapidly growing young rabbits. One group received iron parenterally and thus avoided the postnatal fall in $\mathrm{Hb}$. The other group received no supplement and thus demonstrated ordinary development. In order to get a quantitative measure of the changes in erythropoietic activity throughout the study, Rt prod and $\mathrm{Hb}$ mass were estimated.

\section{EXPERIMENTAL PROCEDURE}

General. To secure a marked fall in $\mathrm{Hb}$, relatively small litters of rapidly growing animals were used (14). Anesthesia and blood sampling were performed as previously described (16). The animals remained with the mother throughout the observation period, but had the choice of food pellets from the age of 21 days.

Determination of relationship between plasma $E S F, H b$, and 
Rt in iron-treated and untreated young rabbits. Two litters, each consisting of six suckling Chinchilla rabbits, were used for the study. At the start of the experiment, 15 days after birth, all animals were weighed and 1.6-ml blood samples were withdrawn for analysis of plasma ESF, $\mathrm{Hb}, \mathrm{Hct}$, and Rt, and calculation of $\mathrm{MCHC}, \mathrm{Rt}$ prod and $\mathrm{Hb}$ mass. Thereafter three animals from each litter were chosen at random and given intramuscular injections of $5 \mathrm{mg}$ of $\mathrm{Fe}^{3+}$ (Jectofer, ASTRA) on the 16th, 18th, 20 th, 23th, 24th, 26th, 27th 31 th, 32nd, and 34th days after birth. The remaining animals served as controls. Weighing and blood sampling were repeated when the animals were 22, 25, 29, and 36 days old. The young rabbits tolerated the blood sampling and injections very well. In the course of the first four blood lettings in total $7 \mathrm{ml}$ blood was removed, corresponding to an Fe loss of about $2.0 \mathrm{mg}$ in the untreated and $2.8 \mathrm{mg}$ in the irontreated group.

\section{ANALYTICAL PROCEDURES}

Standard methods. Hb, Hct, and Rt were determined as previously described $(10,15)$.

Determination of ESF. Plasma ESF was determined by a modification of the cell culture assay for erythropoietin described by Hågå and Falkanger (17), using hepatic erythroid colony forming cells from newborn WLO-mice (18). The assay reflects the net activity of erythropoietin and other stimulatory (2) and possible inhibitory factors. The number of erythroid colonies formed is proportional to this activity in a log dose fashion. The same batch of standard erythropoietin (Sheep plasma erythropoietin step III, Connaught Laboratories, Canada) was used for standardization of the assay and adjustment for interassay variations throughout the study (18). ESF in 24 control cultures with no or $50 \mathrm{mU} / \mathrm{ml}$ standard erythropoietin added, were $50 \pm 9$ and $788 \pm 30$ colonies $/ 0.5 \times 10^{5}$ cells, respectively. The ESF determinations were done in three separate assays, each sample was treated only once.

Calculations. Hb mass was estimated from the body weight and $\mathrm{Hb}$, assuming that the blood volume was $7 \%$ of the body weight (9). This percentage seems to decrease slightly with increasing age (19) and thus the $\mathrm{Hb}$ mass probably tends to be slightly overestimated during the last part of the observation period, as compared with the initial part. Corrections were made for the influence of blood letting. Rt prod was estimated from the body weight, Hct, and Rt, assuming that the blood volume was $7 \%$ of the body weight and that the reticulocytes on an average remain recognizable in the blood for $48 \mathrm{~h}(20)$.

\section{STATISTICS}

The level of significance of differences between means was determined in accordance with Student's $t$ test (for paired observations within groups and for unpaired observations between groups). All observations are given as mean $\pm \mathrm{SEM}$.

\section{RESULTS}

The growth was the same in the untreated and the iron-treated rabbits, the weights being $201 \pm 27$ and $208 \pm 27 \mathrm{~g}$ on the 15 th day, and $458 \pm 65$ and $466 \pm 78 \mathrm{~g}$ on the 35th day, respectively $(p>0.05)$.

The untreated group (Fig. 1) showed a marked fall in $\mathrm{Hb}$ from the 15 th to the 29th day $(p<0.001)$, and thereafter a marked rise to slightly below the initial level on the 36 th day. This is the usual development in rabbits at this age $(10,16)$. In contrast, $\mathrm{Hb}$ in the iron-treated group remained essentialy unchanged from the 15 th to the 29 th day, but showed a slight decrease from the 29 th to the 36th day $(p<0.01)$. Initially, on the 15 th day, both groups showed plasma ESF levels indistinguishable from observations in nonstimulated control cultures $(p>0.05)$. This also was the case on the 22nd day, despite markedly lower $\mathrm{Hb}$ in the

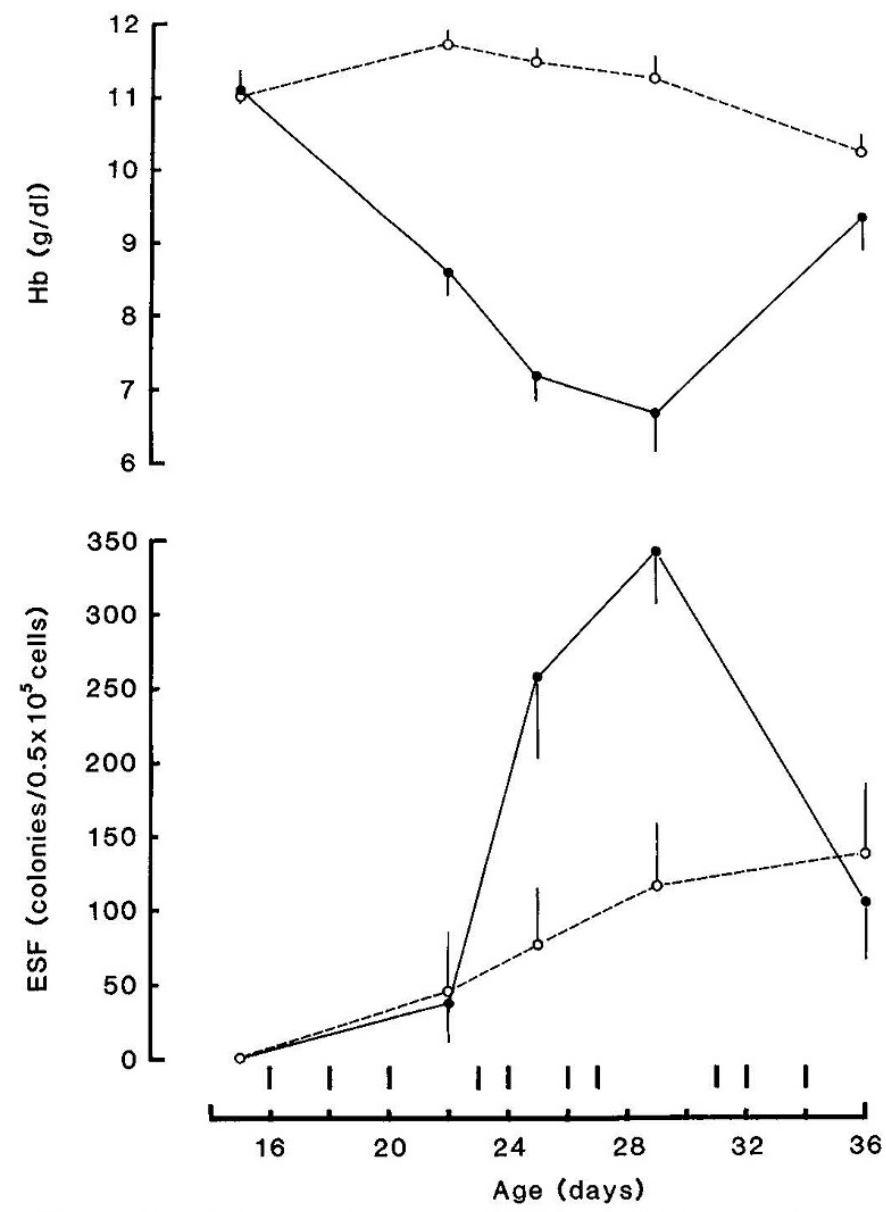

Fig. 1. Hb, ESF, and age in two groups of young rabbits with $(\mathrm{O})$ and without (-) extra iron. The vertical bars designate time of iron supplements (mean values \pm SEM).

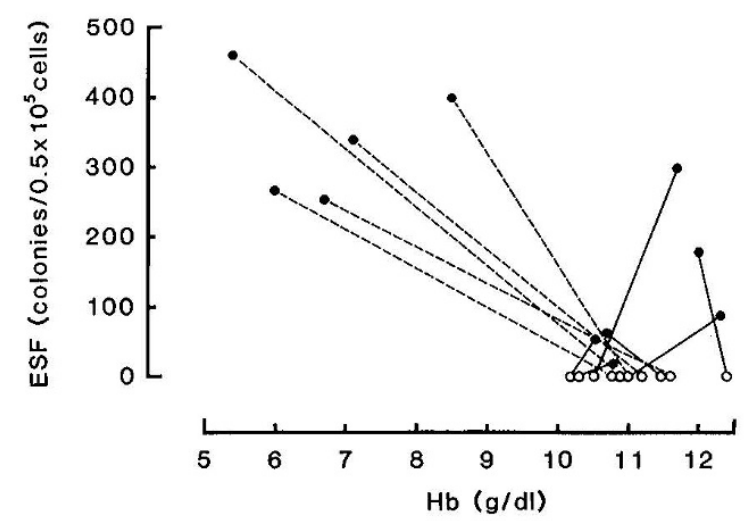

Fig. 2. ESF and $\mathrm{Hb}$ on the 15 th $(\mathrm{O})$ and 29 th day $(\bullet)$, in young rabbits with $\left(\mathrm{O} \longrightarrow\right.$ ) and without $\left.(\mathrm{O}---)_{-}\right)$extra iron.

untreated animals. Thereafter plasma ESF in the iron-treated group showed a slight, continuous rise, whereas plasma ESF in the untreated group showed a marked, transient rise, reaching maximum on the 29th day, around nadir of the anemia. On the 36th day, however, there was no difference between plasma ESF of the two groups $(p>0.05)$, the level being slightly above the level on the 22nd day $(p<0.05)$. Comparing the individual changes in $\mathrm{Hb}$ and plasma ESF from the 15th to the 29th day (Fig. 2), it appears that the untreated animals, all with a marked fall in $\mathrm{Hb}$, showed a marked rise in plasma ESF. A substantial rise in plasma ESF was, however, also observed in some of the 
Table 1. Rt, Rt prod, Hct, and MCHC in two groups of young rabbits, one without iron supplementation and one given iron intramuscularly 10 times, from the 16 th to the 34 th day postnatally

\begin{tabular}{|c|c|c|c|c|c|c|c|c|c|}
\hline $\begin{array}{c}\text { Age } \\
\text { (day) }\end{array}$ & & \multicolumn{4}{|c|}{ Untreated } & \multicolumn{4}{|c|}{ Iron-treated } \\
\hline 15 & SEM & 1.0 & 0.02 & 0.4 & 0.3 & 0.9 & 0.03 & 1.5 & 0.3 \\
\hline 22 & Mean & 4.3 & 0.14 & 31.2 & 27.7 & 8.9 & 0.39 & 42.9 & 27.3 \\
\hline \multirow[t]{2}{*}{25} & Mean & 4.5 & 0.14 & 26.2 & 27.6 & 8.1 & 0.35 & 40.8 & 28.2 \\
\hline & SEM & 0.7 & 0.03 & 1.2 & 0.3 & 1.6 & 0.05 & 0.7 & 0.2 \\
\hline \multirow[t]{2}{*}{29} & Mean & 9.6 & 0.30 & 25.1 & 26.7 & 5.7 & 0.29 & 39.8 & 28.5 \\
\hline & SEM & 0.9 & 0.03 & 1.5 & 0.6 & 0.6 & 0.04 & 1.3 & 0.2 \\
\hline 36 & Mean & 4.8 & 0.26 & 35.3 & 26.7 & 3.4 & 0.28 & 35.9 & 28.6 \\
\hline
\end{tabular}

iron-treated animals without any marked fall in $\mathrm{Hb}$, and also in animals showing increasing $\mathrm{Hb}$.

Rt was relatively high on the 15 th day in both groups (Table 1). There was a gradual decline to a low level on the 36th day in the iron-treated group. The untreated group showed a marked fall to low values on the 22nd and 25th day. Thereafter, following the rise in plasma ESF, Rt increased markedly. On the 36th day there was no difference between Rt of the two groups. Correspondingly, the estimated Rt prod (Table 1) remained essentially the same throughout the observation period in the iron-treated group, whereas the untreated group showed a slight decline from the 15th to the 22nd and 25th day, but increased to the same level as the iron-treated on the 29th and 36th day. The changes in MCHC (Table 1) for the most part reflect the variation in Rt.

At the start of the study the estimated $\mathrm{Hb}$ mass was the same in the untreated and the iron-treaeted group, being $1.57 \pm 0.21$ and $1.58 \pm 0.18 \mathrm{~g}$, reespectively $(p>0.05)$. Thereafter the $\mathrm{Hb}$ mass in the iron-treated animals rose continuously to $4.17 \pm$ $0.55 \mathrm{~g}$ on the 36 th day. In the untreated group the $\mathrm{Hb}$ mass showed a very modest increase to $2.18 \pm 0.27 \mathrm{~g}$ on the 29 th day, and thereafter a relatively steep rise to $3.63 \pm 0.52 \mathrm{~g}$ on the $36 \mathrm{th}$ day.

\section{DISCUSSION}

Previous studies have shown that the marked postnatal rise in erythrocyte 2,3-DPG and blood $\mathrm{PO}_{2} 50 \%$ in rabbit is independent of $\mathrm{Hb}(15,16)$. Thus, the $\mathrm{O}_{2}$ delivery capacity of the blood in the iron-treated rabbits must have increased markedly in the course of the observation period (15). Accordingly, the slight rise in plasma ESF in these animals (Fig. 1) cannot be ascribed to reduction of tissue $\mathrm{O}_{2}$ tension in the regions regulating erythropoietin production/release (1). Thus the plasma ESF and erythropoiesis increased in an organism with a higher than normal $\mathrm{O}_{2}$ supply.

Since the animals were growing rapidly at this time, it is reasonable to speculate that factors which influence growth in general also may stimulate erythropoiesis, erythropoietin production, or act synergistically with erythropoietin. Previous observations may also be interpreted this way. In mice, plasma ESF remains elevated as long as the mice are growing (11). Further, hypertransfusion of rapidly growing young mice does not totally suppress the production/release of erythropoiesis stimulating factor(s) (13). This is also in accordance with observations in the human. In premature infants there is a positive correlation between plasma ESF and weight gain, but no correlation between plasma ESF and $\mathrm{Hb}(21)$. It should also be noted that it has been shown in vitro that growth hormone potentiates the effect of erythropoietin (22) and that insulin-like growth factor I stimulates the growth of murine erythroid colony-forming cells independent of erythropoietin (23).

In the iron-treated group there was a slight decrease in $\mathrm{Hb}$ from the 29th to the 36th day, despite continued iron supplementation and rise in plasma ESF. This observation supports the view that a change in the regulation of erythropoiesis takes place at this age, coinciding with weaning (14).

The fact that plasma ESF in the untreated animals was the same as in the iron-treated on the 22nd day, despite considerably lower $\mathrm{Hb}$, but was markedly higher on the 25 th and 29 th day, show that hypoxic stimulation only occurred at the nadir of the anemia. This may indicate that the marked rise in 2,3-DPG and the consequent shift of the $\mathrm{O}_{2} \mathrm{Hb}$ dissociation curve to the right which regularly take place at this age $(10,15)$, were sufficient to compensate for the fall in $\mathrm{Hb}$ and prevent tissue hypoxia on the 22 nd day, but not around the nadir of the anemia. However, the difference in estimated $\mathrm{O}_{2}$ delivery capacity of the blood from the 22nd and to the 29th day was probably small, and the marked increase in plasma ESF may also reflect that the regions governing erythropoietin production/release became increasingly sensitive to low $\mathrm{O}_{2}$ tension at this stage of development (10). The rise in plasma ESF could also be due to shift from extrarenal to renal erythropoietin production $(6,24,25)$.

In the iron-treated animals Rt showed a marked decrease from the $15 \mathrm{t}$ to the 36 th $\mathrm{d}$ (Table 1) despite the concomitant moderate rise in plasma ESF (Fig. 1). This could indicate that the in vivo sensitivity of the erythropoietic progenitor cell(s) to the erythropoiesis stimulating factor(s) decreased during the observation period. This is in accordance with observations in mice, showing that the in vitro sensitivity to erythropoietin of the erythroid colony-forming cell decreases during the period of postnatal anemia (26). The data may also suggest that unknown inhibitory factors and/or substrate limitations restricted the erythropoiesis. On the other hand, the simultaneous occurrence of a constant $\mathrm{Rt}$ prod and a rising $\mathrm{Hb}$ mass probably reflects that the erythrocyte population at this age almost totally consists of young cells. Thus, the production of erythrocytes markedly exceeds the destruction of old cells, even at moderate reticulocytosis.

In the untreated animals the estimated Rt prod initially showed a definite decrease, despite rising plasma ESF (Fig. 1). Further, the estimated $\mathrm{Hb}$ mass showed a very modest rise only, until the age of $4 \mathrm{wk}$ in the untreated group whereas it rose continuously in the iron-treated group. These observations are in accordance with previous observations, indicating that the postnatal anemia 
in rabbits is due to lack of available iron and/or other nutritional factors, which is relieved during weaning $(10,14,15)$.

The presented data show that the rise in plasma ESF during the postnatal anemia in rabbits is due only in part to the low $\mathrm{Hb}$. They indicate that hypoxia-independent mechanisms also are involved in the regulation of the production/release of erythropoiesis-stimulating factor(s) at this stage of development. In accordance with observations in other species, these mechanisms could be related to the growth and maturation per se $(6,11,13$, $21,24,25)$.

Acknowledgment. The authors are gateful to Kirsten M. Østbye for excellent technical assistance.

\section{REFERENCES}

1. Fischer JW 1983 Control of erythropoietin production. Proc Soc Exp Biol Med 173:289-305

2. Krystal G 1983 Physical and biological characterization of erythroblast ehancing factor (EEF), a late acting erythropoietic stimulator in serum distinct from erythropoietin. Exp Hematol 11:18-31

3. Finne $P 1968$ Erythropoietin production in fetal hypoxia and in anemic uremic patients. Ann NY Acad Sci 149:497-503

4. Hảgå P. Kristiansen $s 1981$ Role of kidney in foetal erythropoiesis: erythropojesis and crythropoietin in newborn mice with renal agenesis. J Embryol Exp Morphol 61:165-173

5. Thomas RM, Canning CE, Cotes PM 1983 Erythropoietin and cord blood haemoglobin in the regulation of human fetal erythropoiesis. Br J Obst Gyn 90:795-800

6. Zanjani ED, Peterson EN, Gordon AS, Wasserman LR 1974 Erythropoietin production in fetus: role of kidney and maternal anemia. $\mathrm{J}$ Lab Clin Med $83: 281-287$

7. Alippi RM, Giglio MJ, Rio ME, Bozzini CE 1981 Influence of growth rate on the ability of hypertransfusion induced plethora to suppress erythropoiesis in the growing rat. Exp Hematol 9:209-213

8. Carmichacl RD, Orlich D, Lutton JD, Gordon AS 1981 Effects of anemia and hypertransfusion on neonatal marrow and splenic colony-forming units in vitro. Stem Cells 1:165-179

9. Halvorsen K. Halvorsen S 1974 The regulation of erythropoiesis in the suckling rabbit. Pediatr Res 8:176-183
10. Holter PH, Sanengen T, Halvorsen S, Refsum HE 1986 Erythropoiesis stimulating factor(s), erythropoiesis and erythrocyte 2,3-diphosphoglycerate in young rabbits with marked postnatal fall in haemoglobin. Acta Physiol Scand 126:583-587

11. Meberg A, Hågå P, Johansen M 1980 Plasma erythropoietin levels in mice during the growth period. Br J Haematol 45:569-574

12. Porcellini A, Izzi T, Delfini C, Lucarelli G 1976 Effect of hypoxia, hypertransfusion and erythropoietin on neonatal erythropoiesis. Haematologica (Pavia) 61:418-431

13. Sanengen T, Halvorsen S 1985 Regulation of erythropoiesis during rapid growth. Brit J Haematol 61:273-279

14. Halvorsen K, Halvorsen S 1973 The early anemia: its relation to postnatal growth rate, milk feeding, and iron availability. Experimental study in rabbits. Arch Dis Child 48:842-849

15. Holter PH, Halvorsen S, Refsum HE 1984 Erythrocyte 2,3-diphosphoglycerate, $\mathrm{PO}_{2} 50 \%$ and available oxygen in young rabbits with and without postnatal fall in hemoglobin. Pediatr Res 18:154-157

16. Holter PH, Refsum HE 1985 Erythrocyte 2,3-diphosphoglycerate, $\mathrm{PO}_{2} 50 \%$ and available $\mathrm{O}_{2}$ in rabbits with bleeding anaemia superimposed on the early post-natal fall in haemoglobin. Acta Physiol Scand 123:325-329

17. Hågå $\mathrm{P}$, Falkanger B 1979 In vitro assay for erythropoietin: erythroid colony formation in methyl cellulose used for the measurement of erythropoietin in plasma. Blood 53:1172-1181

18. Widerфe TE, Sanengen $T$, Halvorsen S 1983 Erythropoietin and uremic toxicity during continuous ambulatory peritoneal dialysis. Kidney Intern 24(suppl 16):208-217

19. Mott JC 1965 Haemorrhage as a test of the function of the cardiovascular system in rabbits of different ages. J Physiol 181:728-752

20. Ganzoni A, Hillman RS, Finch CA 1969 Maturation of the macroreticulocyte. Br J Haematol 16:119-135

21. Hågå $\mathrm{P}$, Meberg $\mathrm{A}$, Halvorsen S 1983 Plasma erythropoietin concentration during the early anemia of prematurity. Acta Paediatr Scand 72:827-831

22. Golde DW, Bersch N, Haolic C 1977 Growth hrmone: species-specific stimulation of erythropoiesis in vitro. Science 196:1112-1113

23. Kurtz A, Jelkman W, Bauer C 1982 A new candidate for the regulation of erythropoiesis. Insulin-like growth factor I. FEBS Lett 149:105-108

24. Carmena AO, Howard D, Stohlman F Jr 1968 Regulation of erythropoiesis. XXII. Erythropoietin production in the newborn animal. Blood 32:376-382

25. Lucarelli G, Porcellini A, Carnevali C, Carmena A, Stohlman F Jr 1968 Feta and neonatal erythropoiesis. Ann NY Acad Sci 149:544-559

26. Rich I, Kubanek B 1980 The ontogeny of erythropoiesis in the mouse detected by erythroid-colony forming technique. Il. Transition in erythropoietin sensitivity during development. J Embryol Exp Morphol 58:143-155 